meagreness (until quite recently) of the direct evidence of the fossil record. Another is the difficulty which anthropologists so often seem to experience in making their field of study intelligible to the general public.

The first reason scarcely obtains any longer, for the discoveries of the last few years have filled in some of the gaps in the palæontological sequence in a most remarkable way. Now the second difficulty has been shown to be surmountable, for Dr. Howells, in his popular book "Mankind So Far", has not only adopted a style which is eminently readable (not to say entertaining), but has also managed to provide a great deal of important information without assuming any specialized knowledge on the part of the reader. His style is the conversational style of the accomplished popular lecturer, transferred directly into writing without any re-casting or re-phrasing to make it conform to the traditional method of presentation which is so commonly associated with the 'science manual'. The result is extraordinarily successful. For one thing, it makes the subject appear to the ordinary reader as exciting as it really is to the specialist. For another, it serves to emphasize that the science of human evolution (like other sciences) is nothing more than organised common sense and, as such, can be readily comprehended by the nonspecialist. But it has yet another advantage. By reducing arguments which have from time to time been advanced for this or that partisan theory of human evolution from 'academic' phraseology to ordinary conversational style, the author has at the same time reduced them to their proper proportions, and sometimes, it must be confessed, has even shown them to be slightly ridiculous.

Dr. Howells' exposition of the study of human evolution is permeated by a robust common sense and by a welcome sense of humour which seems by no means out of place when he deals with controversies which, in more academic circles, have been conducted with unnecessary acrimony. We would particularly commend his illustrations, which are simple and direct and yet have obviously been carefully planned to clarify and emphasize his arguments with the maximum effect. They certainly achieve their purpose. The student who aspires to a mastery of human palæontology may be well advised to use this book as an introductory study.

\section{MATHEMATICS IN INDIA}

Ancient Indian Mathematics and Vedha

By Prof. L. V. Gurjar. Pp. vi+202. (Poona: Ideal Book Service, 1947.) 6.4 rupees; $10 s$.

$\mathrm{H}^{\mathrm{OR}}$ too long the history of mathematics in India 1 was studied only by scholars suffering under the almost insuperable handicap of belonging to an alien civilization; - but recently a number of Indian mathematicians have made a welcome appearance in this appropriate field. Prof. Gurjar's little book on mathematics up to the twelfth century and on pre-telescopic astronomical instruments is full of interesting material, but its tone is altogether deplorable.

European scholars began to study the mathematical classics of India a long time ago-Colebrooke's translation of the "Lilavati" was published in 1817and no help from Indians was forthcoming; the language was dead as well as foreign, the background had to be inferred, the idiom was enigmatical, and these pioneers made some of the mistakes which Prof. Gurjar would make if he attempted to translate "The Crafte of Nombrynge" or Chaucer's "Astrolabe" from imperfect contemporary manuscripts and was unable to find one Englishman competent to discuss his difficulties with him. Nor did the Europeans approach their task without taking for granted that the history of mathematics in India would fit into the story of mankind as they knew it : there was a road from Athens to Bologna and Paris and Oxford through Alexandria and Baghdad, and if mathematics was found to have been cultivated in medieval India, there must be another road from Greece to be traced.

Prof. Gurjar has still to learn to correct what he believes to be a mistake without jeering at it, and to challenge an assumption without resenting it as a deliberate insult to his people. To traduce scholars no less honest than himself is no way to impart a sense of confidence in his own interpretations of ancient texts. At the end of his account of Bhäskaräcärya's work on indeterminate equations, he writes: "To deny the due credit and the honour to the Hindus, is a sheer obstinacy which only the prejudiced Western scholars are capable of having". But what, in fact, did Cajori, of whom Prof. Gurjar complains again and again, write in 1894 ? "The perversity of fate has willed it, that the equation ... should now be called Pell's problem, while in recognition of Brahmin scholarship it ought to be called the 'Hindoo problem'. It is a problem that has exercised the highest faculties of some of our greatest modern analysts. By them the work of the Hindoos was done over again." And on another page : "It is remarkable to what extent Indian mathematics enters into the science of our time. Both the form and the spirit of the arithmetic and algebra of modern times are essentially Indian and not Grecian." This is the very language that Prof. Gurjar wants us to use. Cajori, it is pertinent to observe, is not an orientalist drawing conclusions from his own discoveries; he is a historian reducing to the scale required for a comprehensive work the cumulative judgment of the actual investigators. Nevertheless, Prof. Gurjar roundly accuses the Western scholars, with the explicit exception of Hankel, of "hesitating to record the credit to the Indians simply because they are Indians".

A protest must be made. Burton was warning the British a century ago to be under no illusions as to the feelings of Indians towards them. The mathematicians of Britain bear as citizens their share of responsibility for their country's failures, but they can claim that as mathematicians they have consistently offered not patronage and generosity but appreciation and partnership; the names of Mukhopadhyay and Paranjpye and Rajan, of Naraniengar and Prasad and Vaidianathaswami and a score of others, as well as the great name of Ramanujan, have been honoured equally at Cambridge and in their own land. Surely we have earned the right to expect from Indian mathematicians at this critical moment that whoever else prepares for the future in terms of hatred, they at least will proclaim the reality of interdependence, and the possibility of mutual respect and ultimate friendship. The nursing of grievances has perhaps caused more misery than any other uncivilized habit of mankind; to add one untrue word to the tragic tale of past wrongs is wanton mischief, and to create a legend of injustice is an infamy.
E. H. Neville 